\title{
Pemanfaatan Progressive Web Apps Pada Web Akuntansi
}

\author{
Grace Levina Dewi $^{1^{*}}$, Suhatati Tjandra ${ }^{2}$, Ricardo $^{3}$ \\ ${ }^{1,2,3}$ Program Studi Informatika, Institut Sains dan Teknologi Terpadu Surabaya, Jawa Timur \\ Email: ${ }^{1 *}$ gracelevina@ stts.edu
}

(Naskah masuk: 12 Feb 2020, direvisi: 13 Apr 2020, diterima: 5 Mei 2020)

\begin{abstract}
Abstrak
Software untuk mengelola data transaksi menjadi laporan keuangan sangat banyak dipakai di berbagai sektor bisnis. Software yang cepat, akurat, reliabilitas tinggi serta mudah diimplementasikan menjadi faktor pemilihan software. Oleh karena itu, dikembangkan software pengelola transaksi dengan menggunakan PWA (Progressive Web Apps). Alasan memanfaatkan PWA karena dapat memenuhi kebutuhan software yang dibutuhkan oleh pengguna. Secara garis besar, kelebihan PWA ini terletak pada bagian notifikasi, dapat diakses secara offline, memiliki performa yang bagus, sistem keamanan yang bagus (karena harus menggunakan HTTPS), dan dapat diterapkan pada web. Penerapan PWA ini juga sama seperti memakai aplikasi di smartphone. Uji coba dalam pengembangan ini dilakukan dengan dua metode, yaitu Performance Testing dan Functionality Testing. Hasil uji coba menyatakan bahwa web akuntansi dengan PWA mempunyai kecepatan yang hampir sama dengan native tetapi User Experience PWA lebih baik dibandingkan aplikasi native. Hasil dari Functionality Testing menunjukan Web App dapat berjalan dengan baik sesuai fungsi setiap fitur.
\end{abstract}

Kata Kunci: Progressive Web Apps, Porto, SAP, website, Quasar.

\section{The Use of Progressive Web Apps on Accounting Web}

\begin{abstract}
Software for managing transaction data into financial statements is widely used in various business sectors. Software which is fast, accurate, high reliability and easy to implement is a software selection factor. Therefore, transaction management software was developed using PWA (Progressive Web Apps). The reason to use PWA is because able to meet the software requirements needed by the users. Broadly speaking, the advantages of this PWA lies on the notification section, can be accessed offline, has good performance, a good security system (because it must use HTTPS), and can be applied to the web. The application of PWA is also the same as using an application on a smartphone. Testings in this development are carried out by two methods, namely Performance Testing and Functionality Testing. The testing results state that the Web App with PWA has almost the same speed as native but the PWA User Experience is better than native application. The results of Functionality Testing show the Web App can run properly according to the function of each feature.
\end{abstract}

Keywords: Progressive Web Apps, Porto, SAP, Website, Quasar.

\section{PENDAHULUAN}

Mengetahui kesehatan perusahaan merupakan hal yang vital bagi setiap perusahaan. Laporan kesehatan perusahaan dapat digunakan sebagai indikasi untuk mengambil keputusan yang penting. Laporan ini dibuat dengan mengorganisir data transaksi dan aktivitas keuangan yang terjadi pada perusahaan tersebut. Sistem informasi akuntansi merupakan sistem yang digunakan untuk mengorganisir data keuangan dan transaksi untuk membuat laporan keuangan yang digunakan untuk indikasi kesehatan keuangan perusahaan tersebut [1].

Sistem informasi akuntansi tidak cukup untuk menyelesaikan masalah reliabilitas data. Data yang dihasilkan harus dikirim ke user dengan cepat serta akurat. Oleh karena itu Progressive Web Apps diimplementasikan pada sistem informasi akuntansi untuk meningkatkan kinerja serta reliabilitas data. Progressive Web Apps adalah teknologi Web App yang dikembangkan oleh Google. PWA adalah teknologi caching data dan file yang akan diminta oleh sistem. 
Progressive Web Apps (PWA) adalah aplikasi web yang memuat seperti halaman web tetapi dapat menawarkan fungsionalitas pengguna seperti bekerja offline, notifikasi, dan akses perangkat keras. PWAs mempunyai karakteristik dapat diandalkan, cepat, dan menarik [2]. Berikut adalah karakteristik dari PWA [3]:

1) Progressive - kompatibel untuk semua browser dan device.

2) Responsive - dapat beradaptasi pada setiap jenis layar.

3) Conectivity Independent - dapat berjalan pada saat offline atau jaringan tidak stabil.

4) App Like - Web App serperti Native App.

5) Fresh - selalu menyediakan data yang terbaru.

6) Safe - mengunakan koneksi yang terenkripsi (HTTPS).

7) Discoverable - mudah dicari di search engine.

8) Re-engageable - mudah untuk membuka Web App lewat notifikasi.

9) Installable - dapat diinstal ke mobile device.

10)Linkable - mudah membagikan web app melalui link.

Service worker adalah sebuah script yang browser jalankan di background terpisah dari web page sehingga tidak memerlukan interaksi web page atau user. Sekarang service worker sudah mendukung penggunaan fitur seperti push notification dan background sync. Service worker merupakan JavaScript worker, sehingga tidak bisa mengakses DOM (Document Object Model) secara langsung.

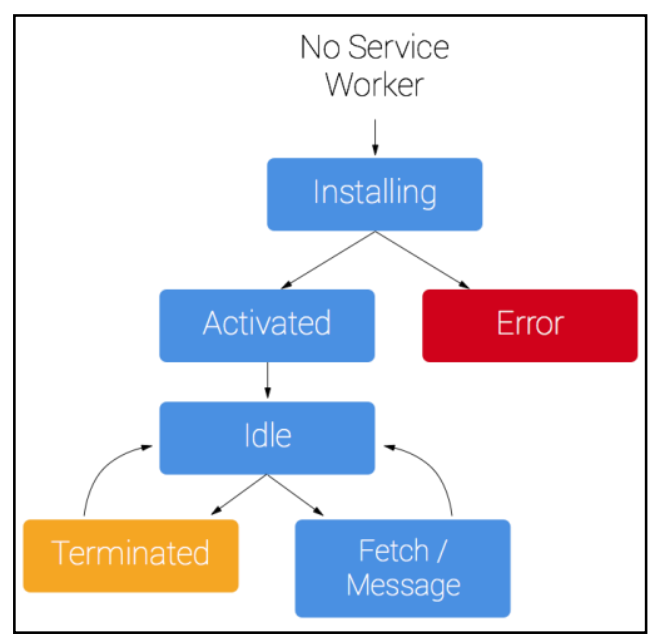

Gambar 1. Daur Hidup Service Worker

Gambar 1 adalah daur hidup dari service worker. Service worker punya daur hidup yang sepenuhnya terpisah dari web page. Proses instalasi service worker ke situs perlu untuk melakukan pendaftaran terlebih dahulu di JavaScript yang ada di halaman web. Setelah proses pendaftaran berhasil maka browser akan melakukan proses instalasi service worker di background.

Saat melalukan instalasi biasanya akan ada beberapa aset statik yang perlu diletakkan pada cache (data yang sifatnya sementara disimpan pada internal smartphone). Jika semua file sudah selesai disimpan pada cache maka service worker berhasil diinstalasi. Tetapi jika ada file yang gagal disimpan pada cache maka service worker tidak akan dapat ter-install di cache dan tidak akan aktif. File yang gagal dimasukan ke cache akan diproses kembali di cache saat dikunjungi lagi.

Ketika langkah instalasi berhasil, maka langkah pengaktifan akan dijalankan dan pada langkah ini semua cache lama bisa ditangani kembali. Setelah langkah pengaktifan selesai maka service worker sudah bisa mengendalikan semua page yang berada di dalam cakupan. Tapi hal ini tidak akan bisa dilakukan ketika service worker baru pertama kali terdaftar sehingga membutuhkan load page ulang. Saat service worker berjalan akan ada dua kondisi yang akan dilalui yaitu kondisi berhenti untuk menyimpan memori atau kondisi untuk menangani fetch dan message event yang terjadi ketika network request atau message dibuat dari page.

Workbox adalah library service worker yang dikembangkan oleh Google sebagai boilerplate best practice. Library ini berfungsi untuk memudahkan dan mempercepat pembuatan PWA untuk aplikasi web. Beberapa fitur yang ada dalam workbox antara lain: precaching, runtime caching, strategi, request routing, background sync, debugging service worker, kode yang fleksibel, dan sederhana.

Workbox merupakan penerus dari sw-precache dan swtoolbox. Sw-precache hanya library untuk precaching, sedangkan sw-toolbox adalah tool untuk membuat runtime caching. Setelah pembuatan dua tool ini selesai, Google mengembangkan dan mengabungkan keduanya menjadi satu. Tool gabungan tersebut bernama workbox. Selain fitur yang ada di sw-toolbox dan sw-precache, workbox juga menyediakan custom injection service worker dan background sync. Fitur terpenting dalam workbox adalah precaching route mengunakan suatu strategi. Ada lima strategi yang disediakan oleh workbox. Strategi tersebut antara lain:

- Cache First

Strategi cache first sangat baik digunakan untuk resource web statik yang jarang untuk diganti seperti file CSS dan JS. Strategi ini akan menyimpan resource tersebut ke cache setelah pertama kali di-request. Ketika request itu dilakukan lagi, service worker akan mengembalikan data dari cache terlebih dahulu sebelum melakukan request ke server yang sebenarnya. Gambar 2 menunjukkan strategi cache first.

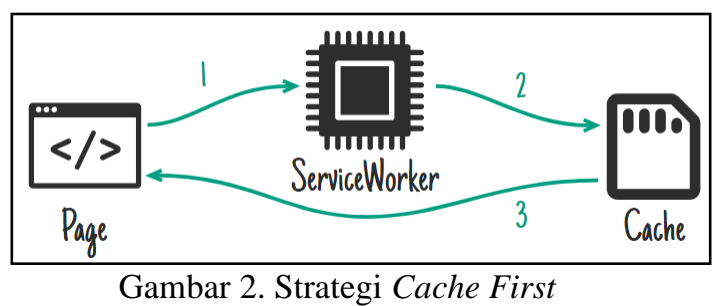

- Cache Only

Strategi cache only baik digunakan untuk plugin yang ada di workbox. Strategi ini lebih baik digunakan ke resource yang tidak mungkin untuk diganti ke depannya. Gambar 3 menunjukkan strategi cache only. 


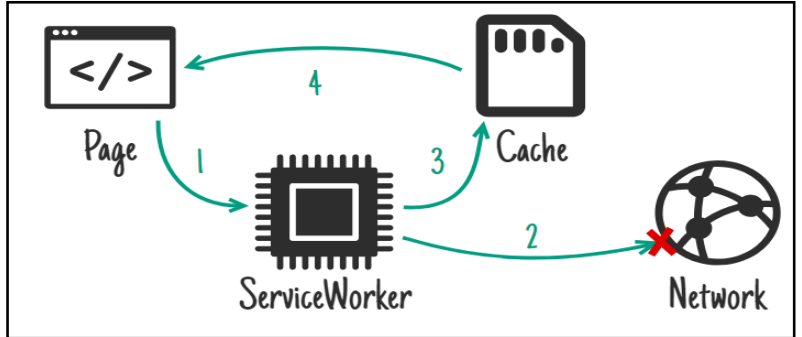

Gambar 3. Strategi Cache Only

\section{- Network First}

Strategi Network First baik digunakan untuk aplikasi realtime yang membutuhkan data dengan realibilitas tinggi. Service worker akan memberi perintah request ke server sesungguhnya. Jika request berhasil, simpan request signature dan data response ke cache serta mengembalikan request ke user. Jika request gagal, cek apakah request signature ada di cache. Jika ada di cache maka kembalikan response dari cache ke user. Gambar 4 menunjukkan strategi network first.

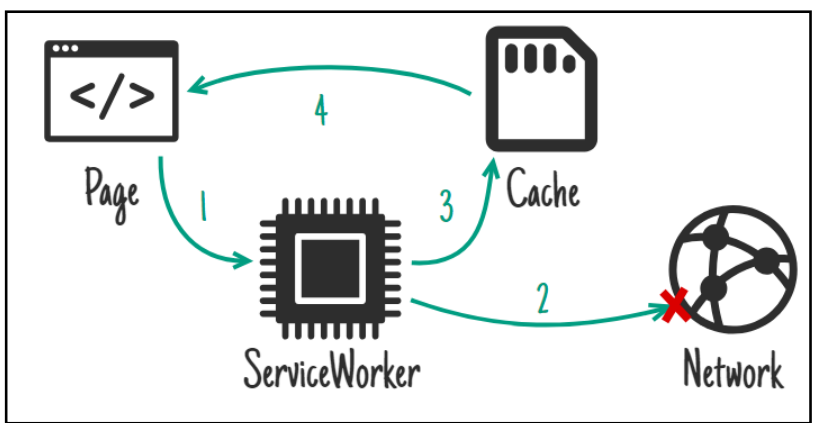

Gambar 4. Strategi Network First

- Network Only

Strategi Network Only tidak ada bedanya dengan request normal ke server dan dikembalikan ke user. Strategi ini tidak mendapatkan cache response. Gambar 5 menunjukkan strategi dari network only.

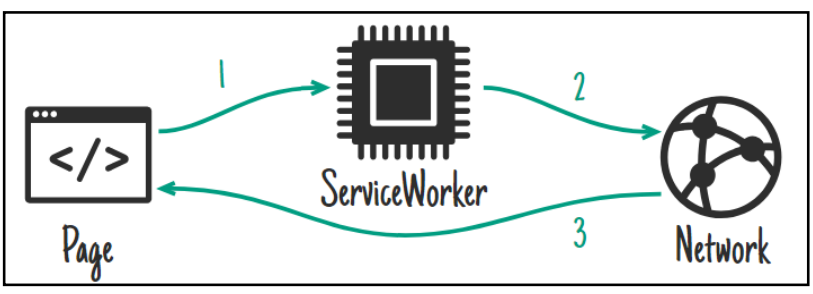

Gambar 5. Strategi Network Only

- Stale While Revalidate

Strategi Stale While Revalidate adalah strategi yang baik digunakan untuk App yang butuh menampilkan data ke user dengan latensi yang sangat rendah. Strategi ini mempunyai banyak kelebihan dibandingkan strategi yang lain. Keuntungan memakai strategi ini sangat jelas, Strategi ini sangat cepat dan responsive. Kerugian untuk mengimplementasikan strategi ini adalah lebih kompleks dibandingkan dengan strategi yang lain. Gambar 6 menunjukkan strategi stale while revalidate.

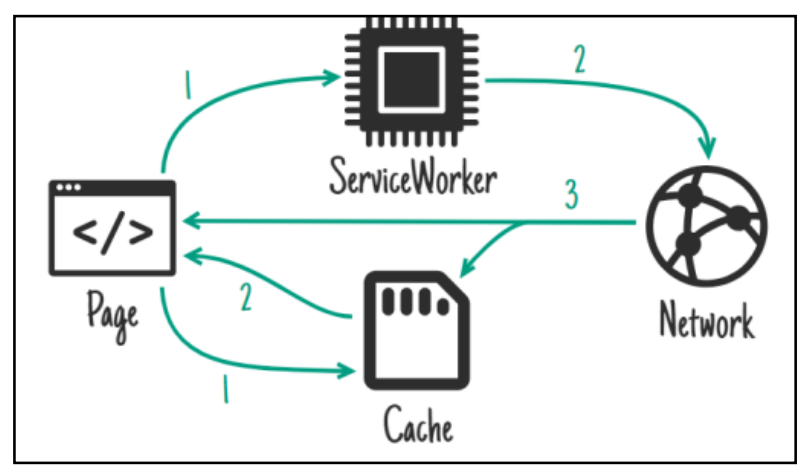

Gambar 6. Strategi Stale While Revalidate

Selanjutnya pembahasan mengenai degin pattern. Design pattern sangat dibutuhkan dalam pengembangan software ini. Tanpa adanya prosedur dan arsitektur yang baik maka lebih sulit untuk mendokumentasikan semua fitur yang ada dalam penelitian. Sistem pada penelitian ini memakai Porto SAP design pattern sebagai arsitektur sistem yang diterapkan. Porto SAP adalah pola arsitektur perangkat lunak modern, yang dirancang untuk membantu pengembang mengatur kode mereka dengan cara yang mudah dikelola [4]. Design Pattern sangat membantu untuk proyek-proyek jangka panjang dan besar, karena mereka cenderung memiliki kompleksitas yang lebih tinggi dengan waktu.

Gambar 7 adalah arsitektur design pattern Porto SAP. Arsitektur dibagi menjadi tiga bagian yaitu framework layer, ship layer, dan container layer. Framework layer adalah layer yang menyediakan package default yang dibutuhkan untuk menjalankan sistem. Ship layer terdiri atas kelas parent dan fungsi helper yang di-share pada semua container. Container layer adalah layer dimana logika bisnis akan diimplementasikan. Gambar 7 menunjukkan design pattern porto.

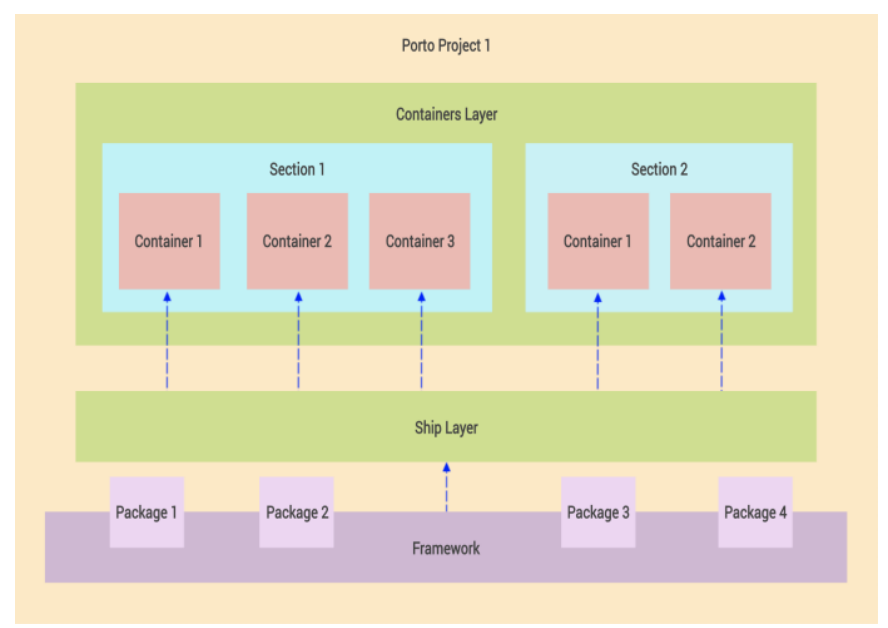

Gambar 7. Design Pattern Porto

Setelah membahas tentang desaign pattern, dibahas tentang web service yang digunakan. Web service adalah suatu sistem perangkat lunak yang dirancang untuk 
mendukung interoperabilitas dan interaksi antar sistem pada suatu jaringan. Web service digunakan sebagai suatu fasilitas yang disediakan oleh suatu website untuk menyediakan layanan (dalam bentuk informasi) kepada sistem lain, sehingga sistem lain dapat berinteraksi dengan sistem tersebut melalui layanan-layanan (service) yang disediakan oleh suatu sistem yang menyediakan web service [5].

Web Service terbagi menjadi dua arsitektur, yaitu: REST (Representational State Transfer) dan SOAP (Simple Object Access Protocol). REST lebih mudah diimplementasikan serta lebih hemat bandwith. Hal ini dibuktikan dengan bagaimana SOAP dan REST merepresentasikan datanya. SOAP mengunakan format XML (Extended Markup Language), sedangkan REST mengunakan format JSON (JavaScript Object Notation). Selain itu untuk dokumentasi SOAP ada strukturnya sendiri sehingga untuk mengimplementasikannya lebih sulit. Penelitian akan mengunakan arsitekur REST.

Front end framework yang diterapkan pada penelitian ini menggunakan Quasar. Quasar merupakan front-end framework berbasis Vue.js yang berlisensi MIT yang bersifat open source [6]. Framework ini ditujukan untuk pengembangan aplikasi berbasis Android maupun iOS yang bersifat hybrid dengan menggunakan HTML, CSS, dan JavaScript [7]. Meskipun aplikasi berbasis mobile ini dibuat dengan menggunakan HTML, CSS, dan JavaScript, tampilan dari aplikasi tidak kalah baiknya dengan aplikasi mobile yang dibuat secara native. Jadi dapat dikatakan, Quasar merupakan sebuah framework website yang sudah menyediakan fitur tampilan responsive untuk aplikasi mobile, sehingga seolaholah seperti sebuah aplikasi mobile yang dibuat secara native.

Quasar bisa digunakan untuk pembuatan aplikasi pada Android (Cordova), iOS (Cordova), Web Apps, dan PWAs. Quasar juga sudah didukung dengan bantuan framework JavaScript yang dikhususkan untuk pembuatan front-end yaitu Vue.js sehingga dapat memperindah tampilan dari desain aplikasi yang telah dibuat dengan Quasar.

Metode pembayaran menggunakan mobile payment. Mobile payment sebagai pendukung metode pembayaran pada penelitian ini menggunkan Midtrans. Midtrans adalah perusahaan yang menyediakan third party payment gateway [8]. API (Application Programming Interface) yang disediakan oleh Midtrans mempunyai banyak metode pembayaran seperti kartu kredit, virtual account, internet banking, bayar melalui Indomaret, dan lain-lain. API ini digunakan untuk menerima pembayaran feature website yang akan diimplementasikan pada penelitian.

Penelitian akan mengunakan SNAP API yang disediakan oleh Midtrans untuk menerima pembayaran. SNAP merupakan portal pembayaran yang memungkinkan merchant untuk menggunakan sistem pembayaran Midtrans dengan memunculkan halaman pembayaran Midtrans langsung di halaman pembayaran. Pemasangan API dari Midtrans mudah dan tidak dikenakan tagihan bulanan, cocok untuk bisnis skala kecil dan menengah. Gambar 8 adalah bagaimana SNAP API bekerja.

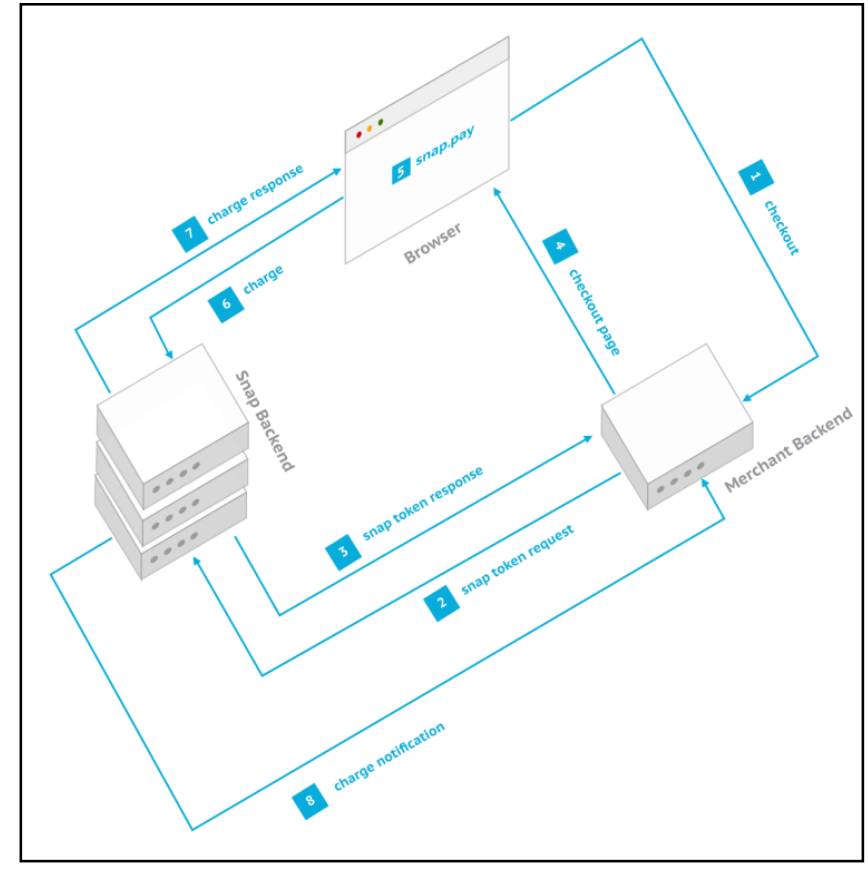

Gambar 8. Arsitektur SNAP API

\section{TAHAPAN PENGEMBANGAN SISTEM}

Penelitian ini membahas mengenai langkah-langkah untuk melakukan pengembangan sistem. Pengembangan ini sangat dibutuhkan untuk mempersiapkan pengerjaan penelitian ini. Langkah-langkah yang dilakukan, sebagai berikut:

- Menganalisis kebutuhan sistem.

Proses analisis yang dilakukan dengan mempelajari software akuntansi yang sudah ada.

- Mengumpulkan plugin dan library yang dibutuhkan.

Plugin dan library digunakan untuk memudahkan implementasi arsitektur yang sudah didesain.

- Membuat back end server.

Back end server adalah API Server yang berbasiskan framework Laravel dengan wrapper Apiato.

- Mendesain database.

Database dibuat dengan menentukan tabel apa saja yang dibutuhkan, serta relasi antar tabel.

- Membuat database serta tabelnya dan isi default tabel. Setelah desain selesai dibuat, desain tersebut diimplementasikan serta ditambah data default yang ada supaya sistem dapat berjalan

- Mendesain tampilan aplikasi mobile dan menghubungkan dengan API.

Desain interface dengan mengunakan front end framework berbasis Vue.js. Pemanggilan API mengunakan JavaScript Library dengan nama Axios.

- Melakukan uji coba.

Uji coba dilakukan untuk memastikan bahwa Web App yang dibuat dapat digunakan dan tidak ada kendala dalam mengelola sistem. 


\section{SPESIFIKASI KEBUTUHAN}

Pada bagian ini dibahas mengenai spesifikasi kebutuhan yang diperlukan dalam melakukan pembuatan penelitian ini. Kebutuhan yang diperlukan dari segi akuntansi, fitur masingmasing role, dan pemanfaatan dari Progressive Web Apps. Spesifikasi kebutuhan dalam penelitian, yaitu:

- Proses akuntansi, yang merupakan proses utama. Proses ini terdiri dari enam proses utama yaitu validasi dan pembersihan, cek hak akses, modul jurnal, modul COA (chart of account), dan modul template.

- Fitur user dan role yaitu fitur yang menyediakan pengaturan hak akses.

- Fitur akses mobile, yang membuat user dapat mengakses sistem dari smartphone atau dari tablet. Fitur ini diimplementasikan dengan menggunakan CSS Library Boostrap untuk website dan Quasar yang sudah responsive secara desain.

- Progressive Web Apps adalah fitur yang diimplementasikan untuk meningkatkan kinerja serta reliabilitas data. Tampilan responsive merupakan hasil dari framework Quasar dengan Vue.js.

- Fitur Push Notification menunjukkan bahwa proses service worker bekerja pada proses yang berbeda dengan browser. Hal ini dibuktikan dengan notifikasi muncul walaupun browser atau Web App telah ditutup. Notifikasi dapat di buat saat suatu event terjadi seperti stok habis atau ada pembayaran yang belum dibayar.

- Fitur pembayaran dari customer. Fitur ini mengimplementasikan Midtrans Payment Gateway Fitur ini dapat terjadi setelah customer melakukan checkout pada keranjang belanja. Fitur ini membutuhkan client key dan secret key dari dashboard Midtrans untuk bisa menerima pembayaran dari customer. Key dari Midtrans dapat dimasukan pada halaman menu settings. Gambar 9 merupakan tampilan dari Midtrans Payment Gateway.

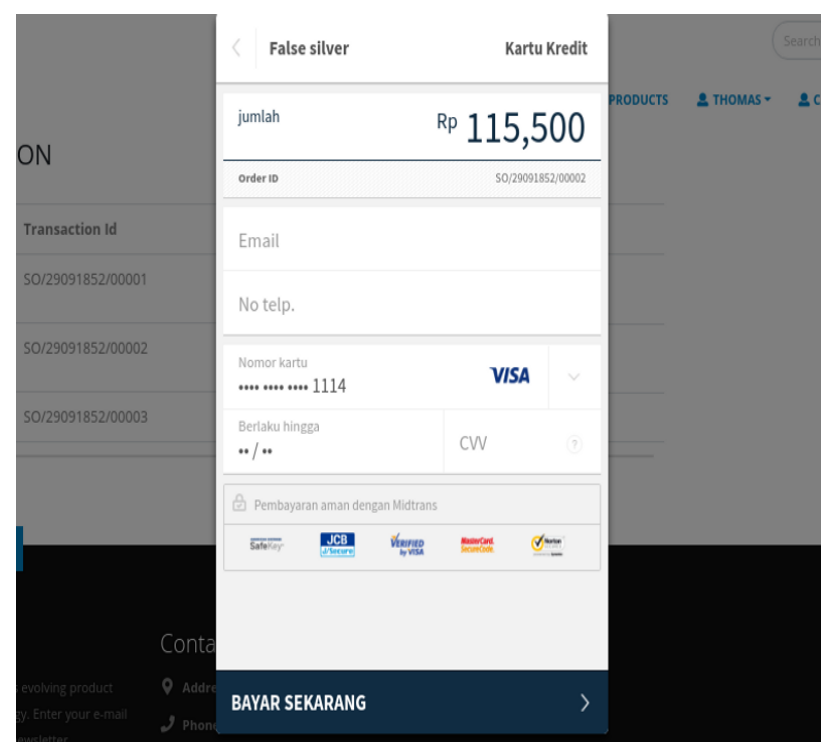

Gambar 9. Midtrans Payment
- Background Sync adalah fitur Progressive Web Apps yang akan menyimpan request gagal karena ganguan konektivitas. Request yang gagal akan disimpan pada index $D B$ dan saat browser merasa terkoneksi ke internet request tersebut akan dikirim kembali untuk dijalankan.

\section{DESAIN SISTEM}

Modul Jurnal mengambil data dari template dan membuat jurnal entri untuk membukukan transaksi sesuai dengan template yang telah diatur sesuai dengan sistem debit dan kredit. Modul COA merupakan proses yang mengelola chart of account. Pada Gambar 10 menunjukkan DFD (Data Flow Diagram) pada proses akuntansi.

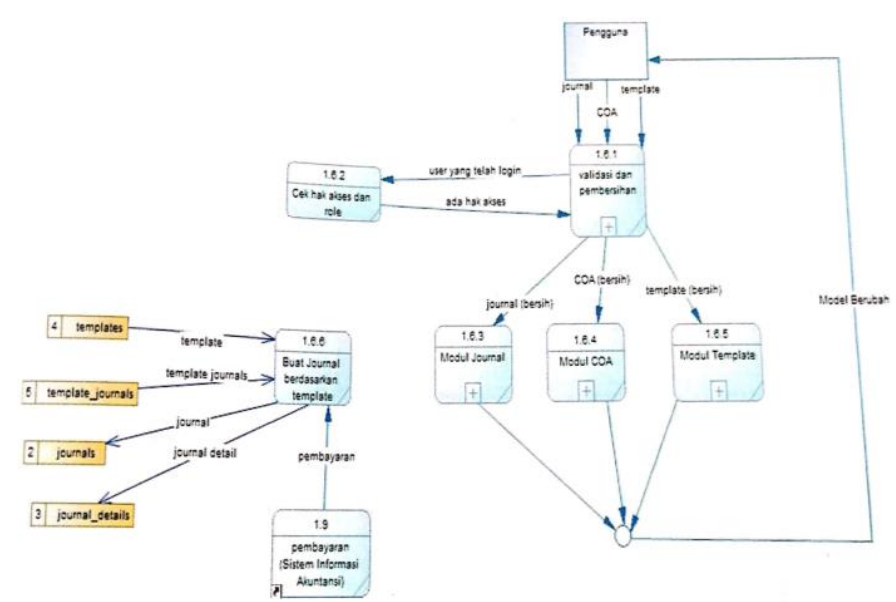

Gambar 10. DFD Proses Akuntansi

\section{UJI COBA}

Uji Coba dilakukan dengan dua metode, yaitu Functionality Testing dan Performance Testing. Functionality Testing adalah metode uji coba dengan mencoba fungsi yang dibuat satu per satu (Black Box Testing). Performance Testing adalah benchmark yang mengunakan tool Lighthouse dan GTMetrix.

\section{A. Functionality Testing}

Functionality Testing merupakan jenis pengujian blackbox yang mendasarkan uji kasusnya pada spesifikasi komponen perangkat lunak yang diuji. Fungsi diuji dengan memberi masukan dan memeriksa output, dan struktur program internal jarang dipertimbangkan (tidak seperti pengujian white-box). Pengujian fungsional biasanya menggambarkan apa yang dilakukan sistem.

Functionality Testing dilakukan dengan menginputkan data ke web app dan melihat hasil dari inputan tersebut apakah output sesuai dengan harapan. Functionality Testing hanya dilakukan pada fitur yang penting pada penelitian ini, yaitu fitur PWA. Functionality Testing dilakukan dengan beberapa perangkat yaitu Redmi Pro 3 (Android), dan notebook HP. Spesifikasi perangkat tersebut dapat dilihat pada Tabel 1. 
Tabel 1. Spesifikasi Perangkat Testing

\begin{tabular}{|c|c|c|c|}
\hline Nama & Layar & OS & Browser \\
\hline $\begin{array}{l}\text { Redmi } 3 \\
\text { Pro }\end{array}$ & $\begin{array}{l}5 \%(720 \times 1.280) \\
\text { pixel }\end{array}$ & $\begin{array}{l}\text { Android } \\
5.1 \\
\text { (Lollipop) }\end{array}$ & Chrome \\
\hline $\begin{array}{l}\text { HP14- } \\
\text { g008AU }\end{array}$ & $\begin{array}{l}\text { 14" diagonal } \\
\text { HD }(1.366 \times 768) \\
\text { piksel }\end{array}$ & $\begin{array}{l}\text { Kali Linux } \\
\text { Rolling }\end{array}$ & Chrome \\
\hline Ipad 3 & $97 ”(24.64 \mathrm{~cm})$ & IOS & Chrome \\
\hline
\end{tabular}

Uji coba juga dilakukan pada fitur PWA adalah fitur utama dari penelitian ini. PWA menyediakan banyak fitur antara lain file caching, runtime caching, push notification, dan background sync. Fitur Background Sync sudah diimplementasikan tetapi fitur ini tidak berjalan sesuai yang diharapkan. Berikut adalah penjelasan hasil uji coba dari fitur PWA:

\section{Progressive}

Uji coba ini dilakukan untuk memastikan PWA yang telah dibuat kompatibel dengan semua browser yang ada. Uji coba ini menggunakan beberapa browser, yaitu: Chrome, Opera, Firefox, Safari, dan Microsoft Edge. Pengujian ini dapat dicek pada bagian inspect element pada halaman web. Berikut uji coba kompatibel PWA dengan mengunakan berbagai browser:

\section{- Chrome}

Chrome adalah browser buatan Google. Uji coba dilakukan dengan Chrome versi 64.0. Gambar 11 adalah bukti bahwa Google Chrome dapat menjalan Fitur PWA dengan baik.

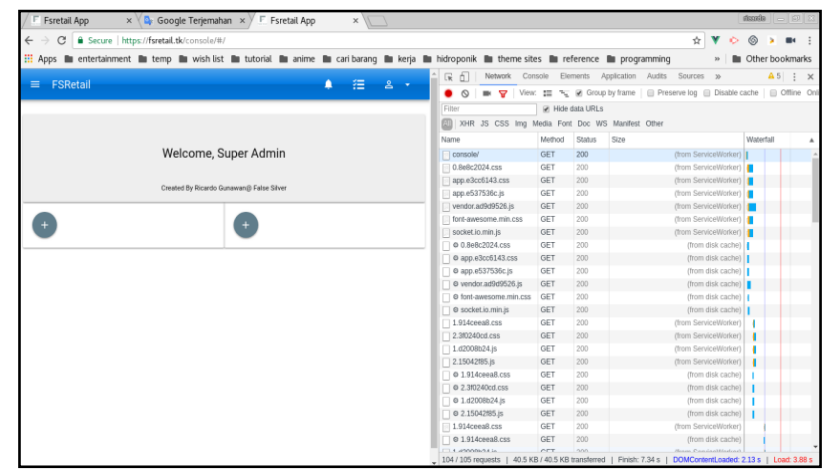

Gambar 11. Uji Coba Browser Chrome

- Firefox

Firefox yang digunakan untuk uji coba adalah browser Firefox versi 63.0. Gambar 12 adalah bukti bahwa PWA dapat berjalan dengan baik pada Firefox.

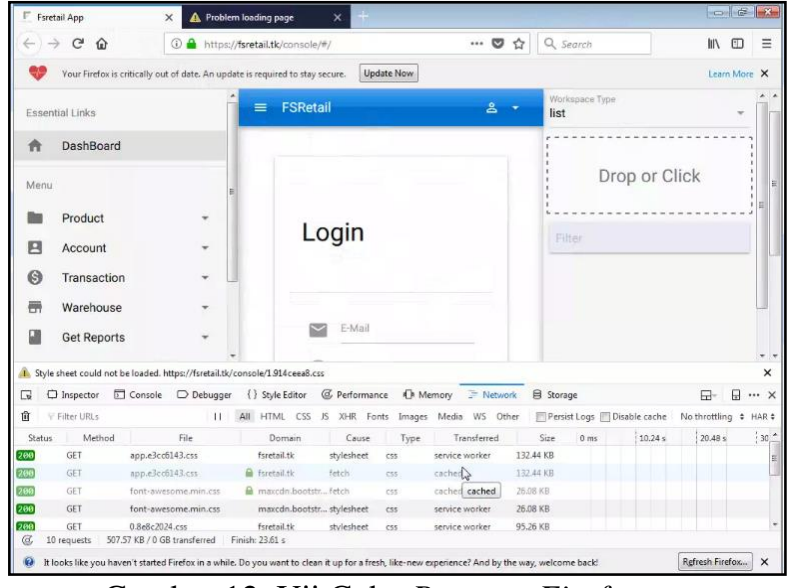

Gambar 12. Uji Coba Browser Firefox

- Microsoft Edge

Browser yang digunakan adalah browser Edge 11. Microsoft Edge tidak mendukung Service Worker. Gambar 13 adalah bukti bahwa browser Microsoft Edge tidak kompatibel dengan PWA. Terdapat pesan error di bagian bawah (bewarna merah).

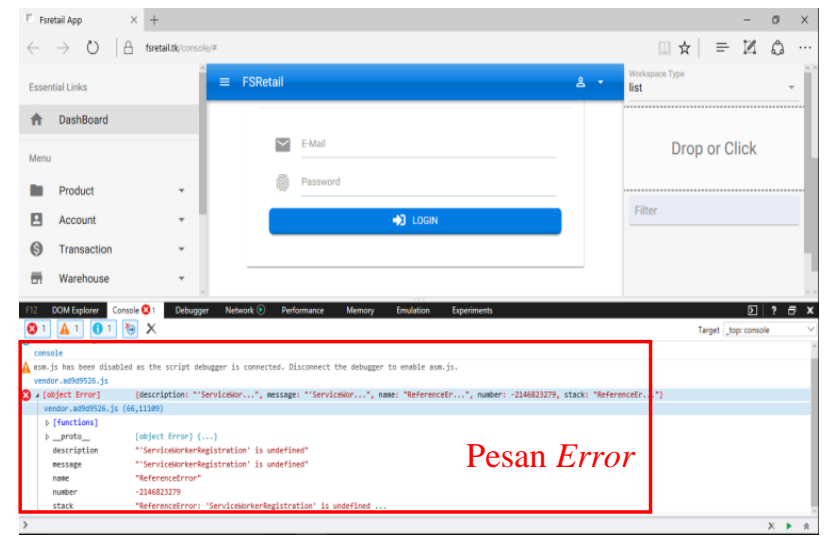

Gambar 13. Uji Coba Browser Microsoft Edge

- Opera

Opera adalah browser yang berbasiskan Chromium. Gambar 14 adalah bukti bahwa browser ini kompatibel dengan PWA. Uji coba mengunakan browser Opera versi 55 .

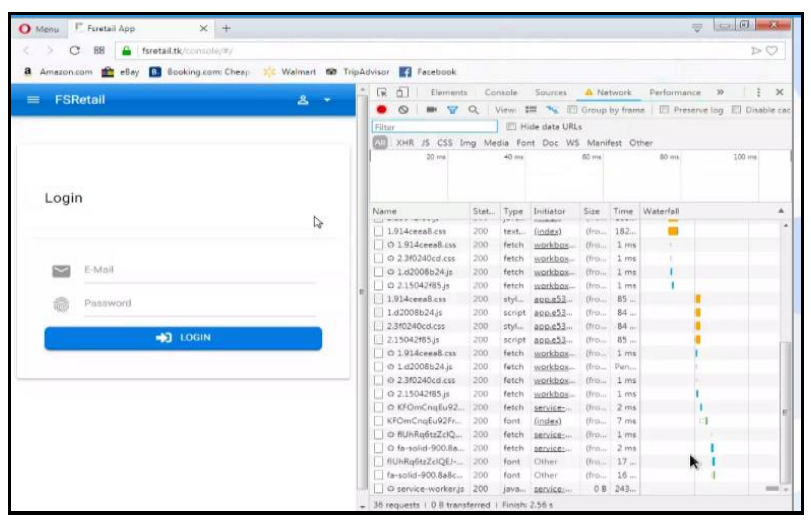

Gambar 14. Uji Coba Browser Opera 
- Safari

Uji coba dilakukan dengan menggunakan browser Safari versi 11. Gambar 15 adalah bukti bahwa browser Safari kompatibel dengan PWA.

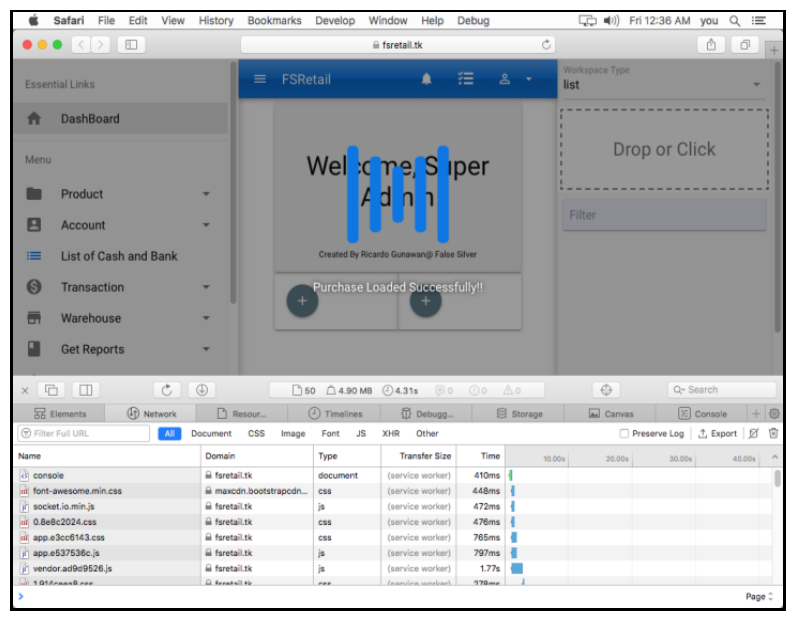

Gambar 15. Uji Coba Browser Safari

\section{File Caching}

Fitur file caching adalah fitur untuk menyimpan file statik (file yang jarang ada perubahan) pada client. Fitur ini diujicobakan dengan cara mematikan koneksi internet pada perangkat yang diuji dan akses halaman konsol (menggunakan library workbook yang sudah memanfatatkan kelima strategi yang sudah dijelaskan sebelumya). Halaman tersebut seharusnya dapat dimuat di browser karena file statik seperti CSS dan JS sudah ada di client. Hanya saja operasi transaksi tidak dapat dilakukan. Fitur untuk menyimpan request gagal dijelaskan pada fitur background sync.

Gambar 16 dan Gambar 17 adalah hasil uji coba dari fitur file caching. Gambar 16 adalah gambar uji coba pada laptop yang sudah diputuskan koneksi internet. Dapat dilihat file statik seperti CSS dan JS telah dikembalikan ke browser sebagai request berhasil walaupun tidak ada koneksi internet. Gambar 17 adalah uji coba pada smartphone Xiaomi Redmi. Fitur ini berjalan dengan lancar pada uji coba ini.

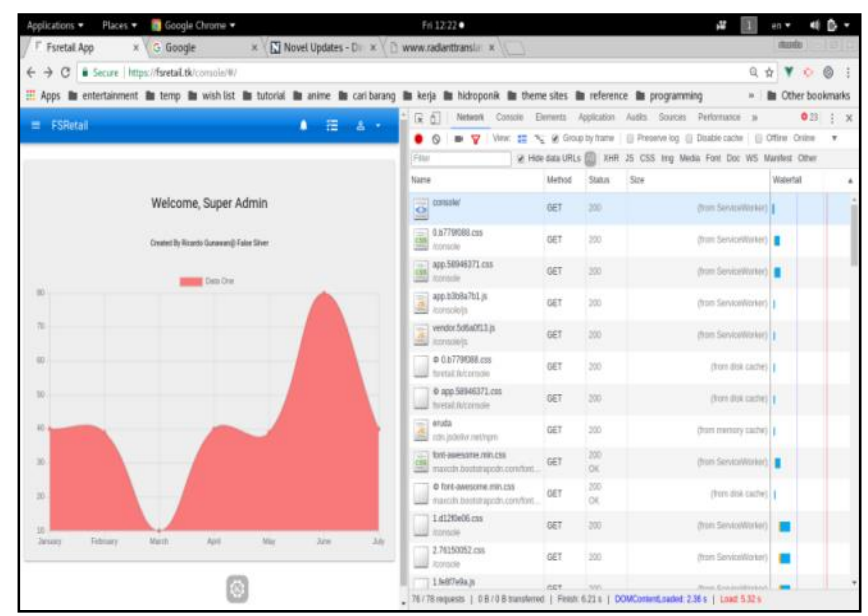

Gambar 16. Uji Coba File Caching Pada Laptop

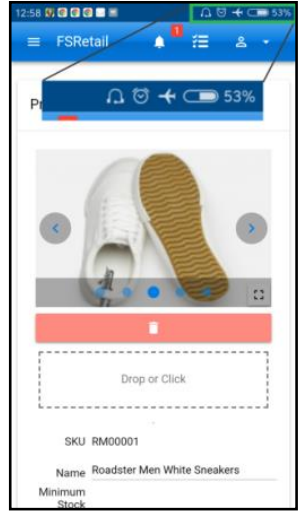

Gambar 17. Uji Coba File Caching Pada Redmi 3 Pro

\section{Runtime Caching}

Fitur Runtime Caching adalah fitur untuk mengingat request yang pernah dilakukan oleh pengguna. Fitur ini hanya menyimpan request yang bersifat dinamis dan request yang sederhana (GET dan POST). Request yang disimpan akan dikembalikan ke pengguna ketika koneksi internet putus.

Fitur ini akan diujicobakan dengan melakukan request ke server backend untuk melihat detail dari sebuah item. Request tersebut mempunyai URL '/item/ $\{\mathrm{id}\}$ ' ini bersifat dinamis karena parameter ID dapat dimasukan dengan ID yang ada di server. Gambar 18 dan Gambar 19 adalah hasil uji coba untuk fitur Runtime Caching. Gambar 18 menunjukkan uji coba yang dilakukan pada laptop dan Gambar 19 adalah uji coba runtime caching pada Redmi 3 Pro.

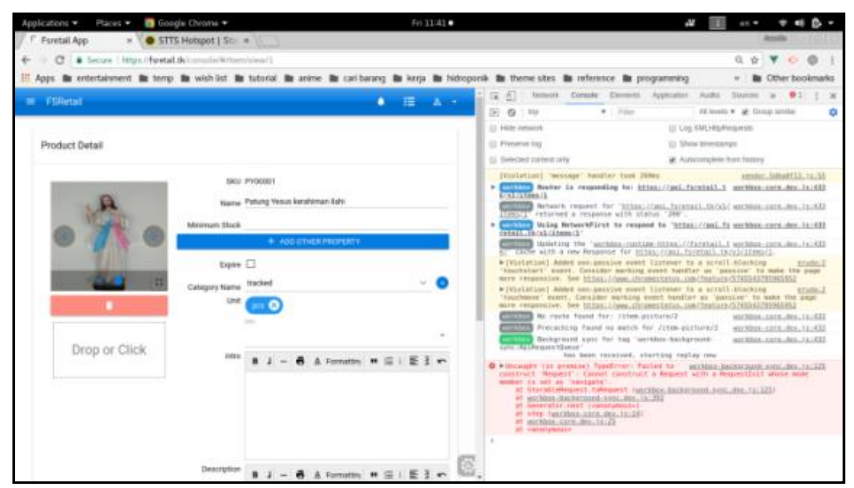

Gambar 18. Uji Coba File Caching Pada Laptop

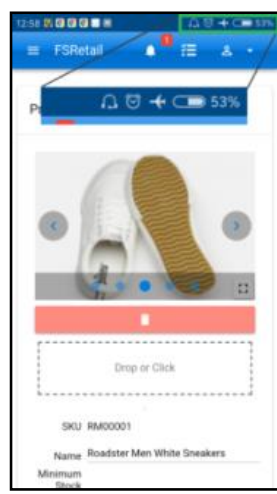

Gambar 19. Uji Coba File Caching Pada Redmi 3 Pro 


\section{Background Sync}

Background Sync adalah fitur PWA yang akan mengingat request yang dilakukan oleh pengguna saat tidak ada akses ke internet. Request tersebut akan dikirim ulang ketika browser merasa koneksi internet sudah dipulihkan. Browser akan memberikan trigger event yang bernama 'sync' ketika perangkat telah terhubung dengan internet. Request yang gagal akan di kirim ulang ke backend server.

Gambar 20 dan Gambar 21 adalah hasil uji coba yang dilakukan pada laptop HP. Gambar 20 adalah proses uji coba dengan memutuskan koneksi ke internet dan melakukan request saat tidak ada koneksi. Gambar 21 adalah pengiriman request yang gagal dengan fitur Background Sync. Dapat dilihat Gambar 21 data sudah diperbarui pada server.

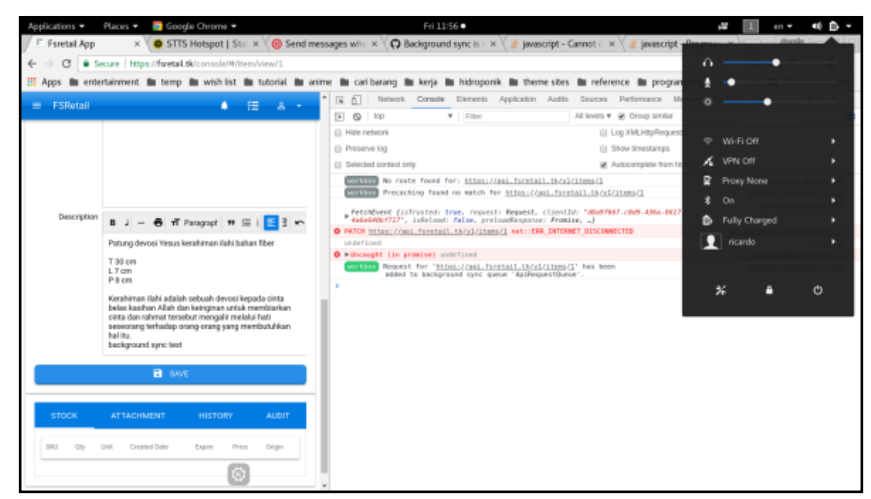

Gambar 20. Uji Coba Background Sync

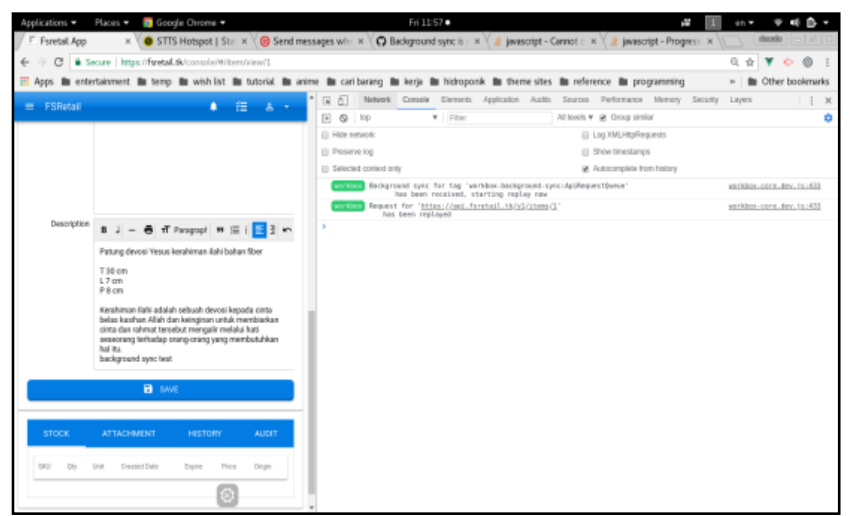

Gambar 21. Uji Coba Background Sync Data Baru

Fitur Background Sync tidak berjalan sesuai ekspetasi. Hal ini diakibatkan oleh Background Sync tidak mendukung request CORS (Cross Origin Resource Sharing). Saat request gagal terkirim request akan tersimpan pada queue background sync untuk dijalankan ulang ketika perangkat online kembali. Request CORS akan mengirim dua request, yaitu: options request dan request asli. Options request digunakan untuk memvalidasi apakah server memperbolehkan CORS dan jika boleh maka request asli akan dikirim. Hal ini menyebabkan jika request gagal queue akan menyimpan request yang pertama yaitu options request bukan request yang asli. Hal ini membuat fitur Background Sync kadang berjalan tidak sesuai dengan ekspetasi.
Gambar 22 dan Gambar 23 adalah hasil uji coba Background Sync menggunakan Redmi 3 Pro. Uji Coba tidak dapat dilakukan dengan melihat Console Developmnet pada perangkat mobile karena Console tidak dapat ditunjukan. Oleh karena itu uji coba dilihat mengunakan apakah data sudah berubah ketika pengguna online. Gambar 22 adalah gambar penambahan string 'Test background sync' pada sebuah deskripsi produk. Perangkat pada Gambar 22 dalam kondisi offline. Gambar 23 menunjukkan perangkat sudah dikoneksikan dengan internet serta halaman sudah di load ulang. Penambahan string 'Test background sync' pada deskripsi produk telah tersimpan ke database dengan adanya fitur Background Sync.

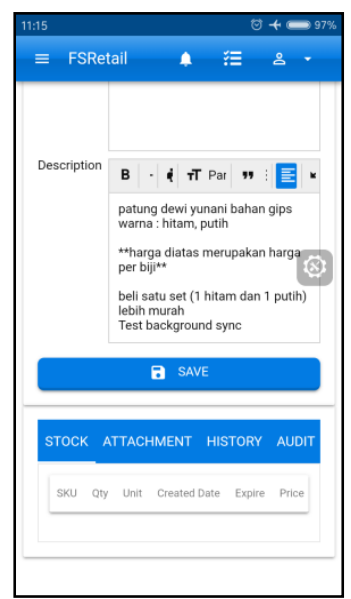

Gambar 22. Redmi 3 Pro Kondisi Offline

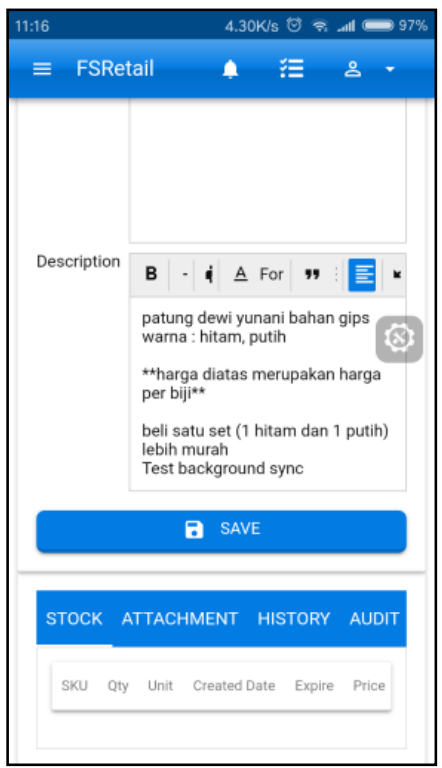

Gambar 23. Redmi 3 Pro Kondisi Online

\section{Push Notification}

Push Notification adalah fitur untuk mengirim notifikasi ke perangkat user. Notifikasi akan terkirim saat customer membayar barang belanjaan, ada pembelian yang jatuh tempo untuk dibayar dan ada penjualan yang jatuh tempo. Push notification diujicobakan secara manual dengan 
menggunakan trigger event tersebut dengan mengunakan PHP console tinker. Gambar 24 dan 25 adalah hasil uji coba dari fitur Push Notification. Gambar 24 adalah uji coba pada laptop HP yang menunjukan notifikasi pada bagian atas layar. Gambar 25 adalah hasil uji coba pada Redmi 3 Pro. Notifikasi sudah masuk dalam notifikasi list dan ada getaran untuk menotifikasi pengguna bahwa ada notifikasi.

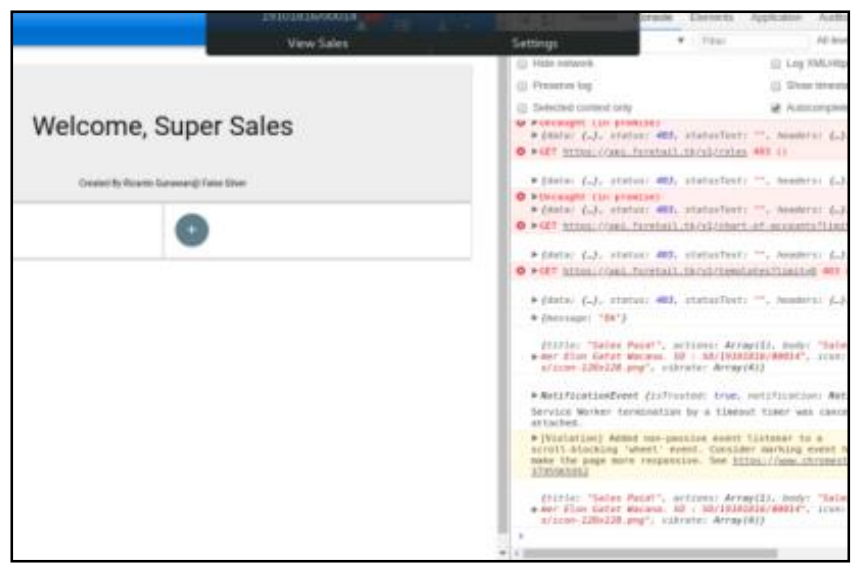

Gambar 24. Uji Coba Push Notification Pada Laptop

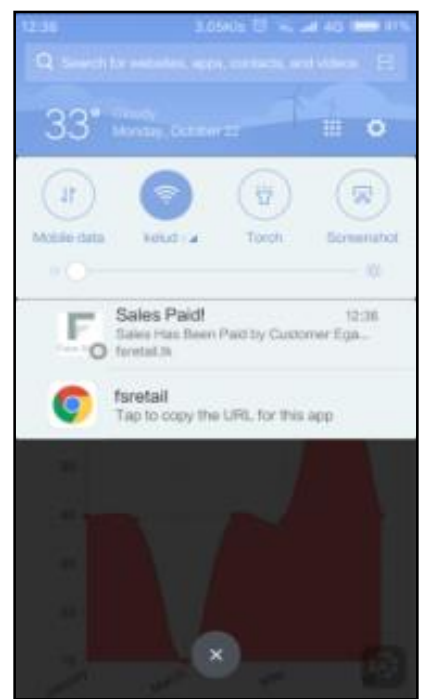

Gambar 25. Hasil Push Notification Pada Redmi 3 Pro

\section{B. Performance Testing}

Uji Coba ini akan mencoba bagaimana kinerja yang dilakukan dengan dua benchmark yaitu Lighthouse dan GTMetrix. Light House adalah software open source untuk meningkatkan kualitas aplikasi web dengan menilai source code dari aplikasi web tersebut [9]. Light House mejalankan serangkaian pengujian terhadap web dan digunakan untuk benchmark apakah web app sudah mengunakan Best Pratice dan Service worker sudah berjalan dengan baik. Gambar 26 adalah hasil benchmark dari Lighthouse. Nilai yang ditujukkan adalah nilai PWA (pemanfaatan Progressive Web Apps) sebesar 91\%, Accessibility (kemudahan pengaksesan website) $89 \%$, dan Best Practice (efisiensi penggunaan website) sebesar $94 \%$.

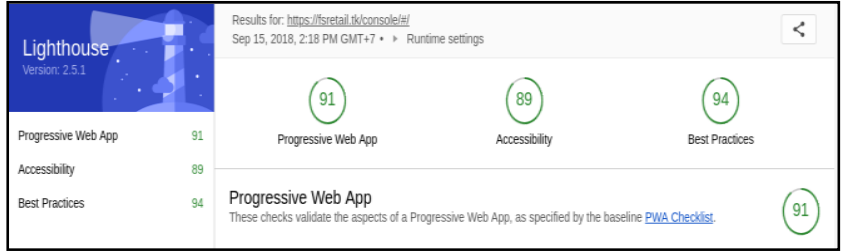

Gambar 26. Benchmark Light House

GTMetrix adalah performance benchmark untuk mengukur bagaimana kecepatan load dari suatu website, yang memungkinkan pemantauan $U R L$ setiap jam dari lokasi yang berbeda sehingga bisa didapat gambaran lengkap mengenai kinerja web [10]. Gambar 27 adalah hasil Benchmark perbandingan antara GTMetrix menggunakan PWA dan native. Dari hasil banchmark kecepatan load time tidak terlalu signifikan, yaitu: 0,5 detik (didapatkan dari selisih waktu pengujian PWA yang memakan waktu sebesar 4,1 detik dengan pengujian Native yang memakan waktu sebesar 4,6 detik).

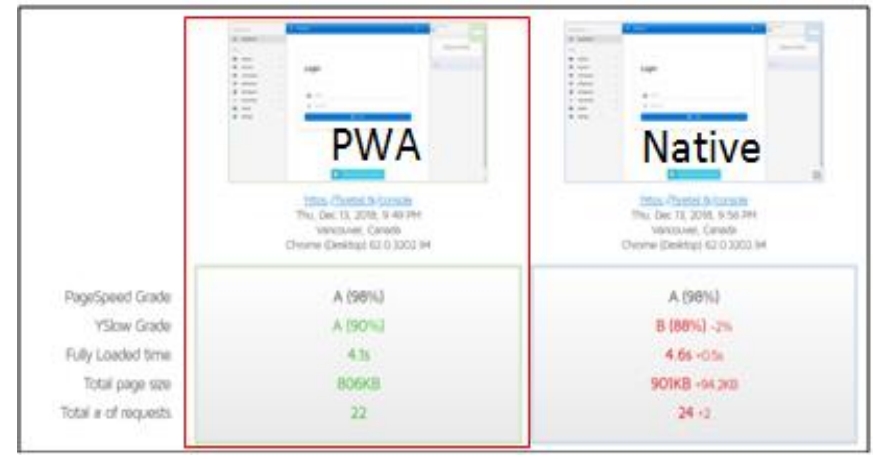

Gambar 27. Benchmark GTMetrix

\section{KESIMPULAN}

Dari hasil uji coba aplikasi yang dikembangkan, terdapat tiga kesimpulan yang bisa diambil dari hasil uji coba. Pertama, Progressive Web Apps adalah teknologi internet yang digunakan untuk memecahkan masalah realibilitas data. Hal ini dapat dibuktikan dengan fitur file caching, runtime caching, dan background sync. Progressive Web Apps merupakan fitur yang harus digunakan untuk generasi Web App selanjutnya, karena dapat membantu kecepatan load dari website.

Kedua, pada ujicoba hasil benchmark dari Lighthouse menunjukkan nilai PWA (pemanfaatan Progressive Web Apps) sebesar 91\%, Accessibility (kemudahan pengaksesan website) $89 \%$, dan Best Practice (efisiensi penggunaan website) sebesar $94 \%$. Kesimpulan terakhir, fitur Background Sync tidak berjalan sesuai ekspektasi. Hal ini telah diujicobakan dengan request sebelum dan setelah offline. Hal ini dapat diatasi dengan menggunakan CORS (Cross Origin Resource Sharing) yang ada dari Quasar Framework. 


\section{REFERENSI}

[1] Porter, D. (2001). Financial Accounting. Virginia: Tidewater Community College.

[2] Adi, L. (2017). Platform E-Learning untuk Pembelajaran Pemrograman Web Menggunakan Konsep Progressive Web Apps. Surabaya: Jurnal Teknik ITS, Vol. 6(2), pp. A579-A583.

[3] Tandel, S. (2018). Impact of Progressive Web Apps on Web App Development. International Journal of Innovative Research in Science, Engineering and Technology, Vol. 7(9), pp. 9439-9444.

[4] Zalt, M. (2016). Porto SAP. Diakses dari https://github.com/Mahmoudz/Porto.

[5] Christensen, J.H. (2009). Using RESTful web-services and cloud computing to create next generation mobile applications. Proceedings of the 24th ACM SIGPLAN Conference Companion on Object Oriented Programming Systems Languages and Applications, pp. 627-634.

[6] Gore, A. (2017). Full-Stack Vue.js 2 and Laravel 5. Brimingham: Packt Publishing.

[7] Stoenescu, R. (2015). Quasar Framework. Diakses dari http://quasar-framework.org/.

[8] Midtrans. (2012). Midtrans. Diakses dari https://midtrans.com.

[9] Google Developers. (2017). Lighthouse. Diakses dari https://developers.google.com/web/tools/lighthouse/.

[10] Singh, T. (2014). Performance Testing of Any Website "Gtmetrix Tool". Diakses dari https://gtmetrix.com/ 